\title{
Mengden av organiserte læringsaktiviteter og sammenhengen med studentenes motivasjon, egeninnsats og overordnede tilfredshet med studiet
}

\author{
Eirik Bjorheim Abrahamsen, Dag Husebø, Jon Tømmerås Selvik, Jan Terje Kvaløy \\ Universitetet i Stavanger
}

\begin{abstract}
SAMMENDRAG: I hogskole- og universitetsstudier er det stor forskjell på mengden av læringsaktiviteter som organiseres av institusjonene. Det er med dette utgangspunktet vi i denne studien vil undersøke hvorvidt det er sammenheng mellom mengden av organiserte læringsaktiviteter og studentenes motivasjon, egeninnsats og overordnede tilfredshet med studiet. Tilbakemeldinger fra over 1700 studenter ved Universitetet i Stavanger, samlet inn til Studiebarometeret i 2018 danner grunnlaget for studien. Dataene viser at det ikke er signifikant sammenheng mellom mengden av organiserte læringsaktiviteter og studentenes motivasjon, egeninnsats eller studentenes overordnede tilfredshet med studiet. Dette trenger imidlertid ikke å bety at slike sammenhenger ikke finnes, men at sammenhengene kan være mer komplekse enn hva vi klarer å fange opp i denne studien. Det er med dette grunnlaget at vi avslutningsvis i artikkelen reflekterer og diskuterer rundt ulike didaktiske og pedagogiske forhold som kan ha påvirkning på den undervisningen og læringen som foregår.
\end{abstract}

Nøkkelord: organiserte læringsaktiviteter, motivasjon, studentenes egeninnsats, tilfredshet med studiet

\section{INTRODUCTION}

Norsk høyere utdanning har de seneste årene hatt stor oppmerksomhet på studentenes læring og utbytte av sin utdanning. Regjeringen ga uttrykk for dette gjennom sitt initiativ for å styrke utdanningskvalitet i sektoren med Stortingsmelding 16, Kultur for kvalitet i høyere utdanning. Hovedmålsetningene med meldingen er at høyere utdanning skal være mer krevende og engasjerende for studentene. Studentene skal møtes som ansvarlige deltakere $\mathrm{i}$ egen læring, og integreres godt i det sosiale og akademiske fellesskapet. Videre skal alle studenter møte aktiviserende og varierte læringsformer, der digitale muligheter utnyttes, og hvor studentene skal møte undervisere med god faglig og utdanningsfaglig kompetanse. I tillegg vektlegges det at utdanning og undervisning skal verdsettes høyere $\mathrm{i}$ akademia, at studieprogrammene skal utvikles i samarbeid med arbeidslivet, og at studieprogrammene skal ha tydelige læringsmål, god helhet og sammenheng (Kunnskapsdepartementet, 2017, s. 21).

Studien som denne artikkelen rapporterer, anlegger disse målsetningene med høyere utdanning som utgangspunkt, og fokuserer på sammenhengen mellom å organisere læringsaktiviteter i møte med studentene, og hvordan studentene svarer på spørsmål som berører deres motivasjon, egeninnsats og overordnede tilfredshet med sitt utdanningsløp.

NOKUTs innføring av Studiebarometeret i 2014, har gitt institusjonene og fagmiljøene verdifulle data om hvordan studentene erfarer det å være student ved ulike studieprogram. Med bakgrunn i disse dataene kan institusjonene få økt innsikt, og kan da iverksette tiltak for å forbedre situasjonen. Argumentasjonen som føres i denne artikkelen, er at data og resultater fra Studiebarometeret, må tilnærmes vitenskapelig i fagmiljøene, og gjøres til gjenstand for kritiske analyser, slik at forskningsbaserte beslutninger og tiltak iverksettes lokalt såvel som av nasjonale myndigheter.

Til tross for at flere studier har viet oppmerksomhet til studentenes tilfredshet og studentevalueringer de senere årene (Wiers-Jenssen et. al., 2002; Otnes et. al., 2011; Wiers-Jenssen, 2014; Nerland, 2019; Abrahamsen et. al., 2020), så er det likevel behov for et styrket kunnskapsgrunnlag som både bygger på 
eksisterende kunnskapsgrunnlag og som anlegger både komparative og longitudinelle perspektiver, hevder Damsa et. al. (2015).

Det er også behov for mer kunnskap om hvilke didaktiske tilrettelegginger som er tjenlige for studentenes læring i den enkelte faglige sammenheng, og hvilken rolle organiserte læringsaktiviteter i fagene spiller for studentenes motivasjon og tilfredshet med utdanningen. I ovenfornevnte NIFU rapport Quality in Norwegian Higher Education - A review on aspects affecting student learning (Damsa et. al., 2015), argumenteres det for å koble kvalitetsarbeidet i høyere utdanning tettere til studentenes læringsprosess. Her vises det til at det kan se ut som om studenttilfredsheten er mindre med selve gjennomføringen av læringsforløpet, ved didaktiseringen av fagene; det vil si hvordan utdanningens læringsvirksomhet organiseres og realiseres. I rapporten vektlegges det sammenhengen mellom hyppigere faglige tilbakemeldinger fra universitetslærer og mer studentorienterte læringsformer som involverer studentene som aktive deltakere i egen læringsprosess.

Publiserte metaanalyser med fokus på læring i høyere utdanning, viser til relasjonelle forhold og den sosiale interaksjonen som foregår mellom universitetslærere og studenter. Disse analysene viser at studenters læring og tilfredshet også handler om å bli sett på et personlig nivå, og at undervisningen og studentaktive arbeidsmåter klarer å fange opp dette (Schneider \& Preckel, 2017).

Jakobsen \& Waldenstrøm (2017) viser i sin empiriske studie at det er en sammenheng mellom studentaktive arbeidsmåter og studentenes motivasjon. Deres studium bygger på en organisatorisk omlegging av deres undervisning i bachelorstudiet i matteknologi. Omleggingen innebar å gå fra et mer teoretisk og lærerstyrt organisert emne, til å bli et mer studentaktiviserende emne i tråd med studentenes egne forventninger. Data som ble analysert bygde på studentevalueringer og eksamensprestasjoner, og resultatene viste at studentene vurderte de strukturelle og læringsmessige omleggingene i emnet som både engasjerende og utbytterike. I tillegg viser studien at «De akademiske prestasjonene ble signifikant forbedret gjennom omleggingen av emnet.» (Jakobsen \& Waldenstrøm, s. 325). Dette er funn som korrelerer med amerikanske metaanalyser innenfor STEM-fagene, hvor Freeman et al. (2014) finner en sammenheng mellom studentenes eksamensresultater og det de beskriver som aktiv studentsentret læring i utdanningene. Hyun, Ediger \& Lee (2017) finner tilsvarende, hvor ulike former for aktivisering av studentene, bidrar til større studentengasjement, større student tilfredsstillelse og til bedre eksamensresultater.

Wiers-Jenssen \& Hovdhaugen (2019), er i sin studie knyttet til norsk høyere utdanning, opptatt av forholdet mellom studentenes tidsbruk i utdanningene og utdanningskvalitet. Her understrekes det at flere studier før dem viser at det er svak korrelasjon mellom studentenes tidsbruk og eksamensresultater, og forfatterne argumenterer for at de heller ikke finner en sterk sammenheng mellom studenttilfredshet og tidsbruk (Wiers-Jenssen \& Hovdhaugen, s. 276). Studien viser til at det er studenter som oppgir høy motivasjon som bruker mest tid på sine studier. Samtidig er det en tendens til at «studenter på fag med mye organisert undervisning også har høy gjennomsnittlig studieinnsats totalt» (s. 283), og «at forventninger fra underviserne har en positiv effekt på studieinnsatsen» (s. 284). Studien tar høyde for at det finnes variasjoner mellom studenter innad $i$ enkelte studieprogram og mellom emnene $i$ et studieprogram, samt for at det er usikkerhet rundt målingene og rapporteringen av studentenes egen studieinnsats.

Studiene over viser at det finnes etablert kunnskap som peker i retning av at mengden organisert studiearbeid kan ha korrelasjon med grad av egeninnsats, motivasjon og generell studenttilfredshet blant studentene. Det at mengden læringsaktiviteter organiseres av universitetslærere som kjenner fagenes tenkemåter og ferdighetsdimensjoner kan antas å sørge for variasjon og aktivisering av studentene henimot utdanningenes innholdsdimensjoner og læringsutbytte. Vi stiller følgende forskningsspørsmål: Hvilken sammenheng finner vi mellom mengden av organiserte læringsaktiviteter og studentenes rapporterte motivasjon, egeninnsats og overordet tilfredshet med sitt utdanningsløp? 


\section{METODE}

\subsection{Data}

Som grunnlag for å studere sammenhengen mellom mengden av organiserte læringsaktiviteter og studentenes motivasjon, egeninnsats og overordnede tilfredshet med studiet, så har vi benyttet data fra Universitetet i Stavanger (UiS), samlet inn til Studiebarometeret i 2018. Studiebarometerundersøkelsen er en nasjonal undersøkelse som stiller spørsmål til over 60000 studenter hver høst om deres oppfatninger om kvalitet i studieprogrammer ved norske høgskoler og universiteter (Bakken mfl., 2019). Tabell 1 viser antall studenter som var med på undersøkelsen ved Universitetet i Stavanger i 2018 fordelt på hvert av fakultetene og ved etter- og videreutdanningen.

Tabell 1. Antall studenter ved Universitetet i Stavanger som var med på Studiebarometer-undersøkelsen i 2018 fordelt på hvert av fakultetene og ved etter-og videreutdanningen.

\begin{tabular}{|l|l|}
\hline & Antall studenter \\
\hline Det helsevitenskapelige fakultet & 280 \\
\hline Det samfunnsvitenskapelige fakultet & 426 \\
\hline Det teknisk- naturvitenskapelige fakultet & 405 \\
\hline Fakultet for utdanningsvitenskap og humaniora & 356 \\
\hline Fakultet for utøvende kunstfag & 27 \\
\hline Handelshøgskolen ved UiS & 232 \\
\hline Etter- og videreutdanningen ved UiS & 6 \\
\hline Universitetet i Stavanger (UiS) & 1732 \\
\hline
\end{tabular}

For å studere de nevnte sammenhengene har vi tatt utgangpunkt i følgende 4 spørsmål fra Studiebarometerundersøkelsen:

1. Læringsaktiviteter organisert av institusjonen (inkludert all undervisning og veiledning, samt praksis hvis relevant)

2. Studieprogrammet bidrar til din motivasjon for studieinnsats

3. Jeg er, alt i alt, tilfreds med studieprogrammet jeg går på

4. Egenstudier (lese pensum, gjøre oppgaver, delta i kollokvier og annet gruppearbeid, etc.)

På spørsmål 1 og 4 så skal studentene oppgi svaret i antall timer. På spørsmålene om studentenes tilfredshet og hvorvidt studieprogrammet bidrar til studentenes motivasjon for studieinnsats så gis det en score mellom 1 og 5, der 1 og 5 representerer henholdsvis dårligste og beste score.

Det var i 2018 totalt 1732 studenter fra Universitetet i Stavanger som var med på Studiebarometerundersøkelsen. Dette gav en svarprosent på 59. Svarprosenten nasjonalt var på 48 i 2018 (NOKUT, 2019). Vi anser derfor resultatene i denne analysen for å gi et godt bilde av hva studentmassen ved UiS mener om disse spørsmålene.

Vi har i denne studien valgt å ekskludere data fra studenter som oppgir mer enn 40 timer med organiserte læringsaktiviteter og over 60 timer egeninnsats. Slike registreringer betraktes som feilregistringer. Det var 22 registreringer som dermed ble fjernet både for organiserte læringsaktiviteter ( $>40$ timer registrert) og for egeninnsats ( $>60$ timer).

\subsection{Empirisk tilnærming}

For å studere sammenhengen mellom mengden av organiserte læringsaktiviteter og studieprogrammets bidrag til motivasjon for studieinnsats, lager vi først boksplott av tid brukt på organiserte 
læringsaktiviteter for hver kategori av motivasjon. Vi vil på denne måten få kunnskap om det er sammenheng mellom de to størrelsene. I boksplottene presenteres median, 25- og 75-persentiler, samt høyeste og laveste normalobservasjon. Eventuelle observasjoner utenfor normalområdet markeres som sirkler utenfor linjene for normalområdet. Det etableres en boksplottoversikt for hele universitetet, men også for hvert av fakultetene. Data for fakultet for utøvende kunstfag og for etter- og videreutdanningen ved UiS har blitt utelatt pga få respondenter. Vi har imidlertid benyttes oss av disse dataene når vi studerer sammenhenger for hele universitetet.

For å formelt teste om det er sammenheng mellom tidsbruk og motivasjon så bruker vi Kruskal-Wallis testen (Newbold mfl., 2019). Dette er et ikke-paramaterisk alternativ til vanlig variansanalyse. Vi velger å bruke denne testen på grunn av at tidsbruksfordelingene ikke er normalfordelte. Eneste antakelse denne testen krever er uavhengighet mellom respondentene. Vi finner det rimelig at denne antakelsen er oppfylt her.

Samme type plott og beregninger som beskrevet over benyttes også når vi studerer sammenhengen mellom mengden av organiserte læringsaktiviteter og studentenes overordnede tilfredshet med studieprogrammet.

For å kartlegge mulig sammenheng mellom mengden av organiserte læringsaktiviteter og studentenes egeninnsats, så plotter vi først antall timer med organiserte læringsaktiviteter opp mot antall timer med egeninnsats fra studentene. Vi regner også ut Spearman korrelasjon (Newbold mfl., 2019) mellom disse variablene.

\section{EMPIRISKE RESULTATER OG ANALYSE}

\subsection{Om sammenhengen mellom mengden organiserte læringsaktiviteter og studieprogrammets bidrag til motivasjon}

For å studere sammenhengen mellom mengden av organiserte læringsaktiviteter og studieprogrammets bidrag til motivasjon for studieinnsats, tar vi utgangspunkt i svarene fra studentene på spørsmål 1 (Læringsaktiviteter organisert av institusjonen) og spørsmål 2 (Studieprogrammet bidrar til din motivasjon for studieinnsats).

Vi lager først et boksplott for dataene for hele UiS. Resultatet er vist i Fig. 1. Fra boksplottet så er det ingenting som skulle tilsi at det er sammenheng mellom tid brukt på læringsaktiviteter organisert av institusjonen og studieprogrammets bidrag til studentenes motivasjon for studieinnsats. Kruskal-Wallis testen gir en $\mathrm{p}$-verdi $=0.56$, dvs. ingen signifikant sammenheng.

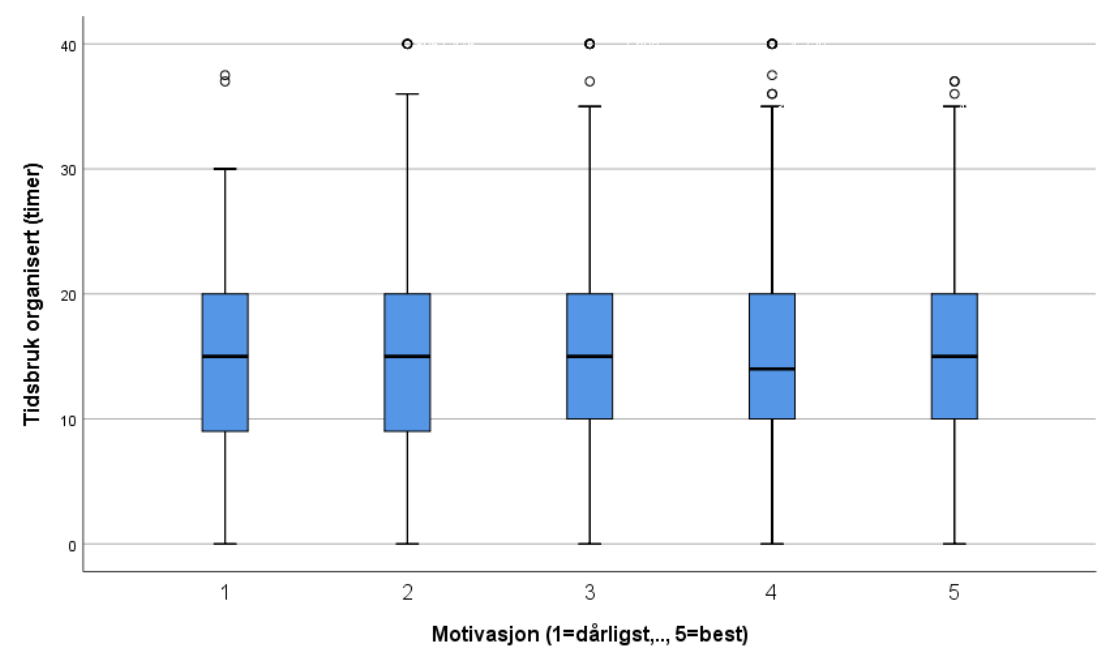


Fig. 1. Antall timer pr. uke med organiserte laeringsaktiviteter ved UiS plottet opp mot studentenes svar på hvorvidt studieprogrammet bidrar til motivasjon for studieinnsats.

De samme analysene som beskrevet over er også gjennomført på fakultetsnivå. Fra Fig. 2 så ser det ut til at resultatene på fakultetsnivå er sammenfallende med resultatene fra hele universitetet. Vi får med andre ord, også her, indikasjon på at det ikke er sammenheng mellom mengden av organiserte læringsaktiviteter og studentenes svar på hvorvidt studieprogrammet bidrar til motivasjon for studieinnsats.

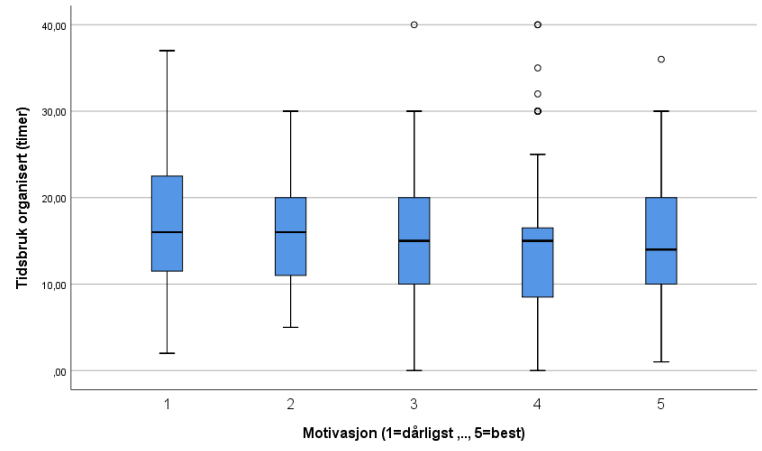

Fakultet for utdanningsvitenskap og humaniora

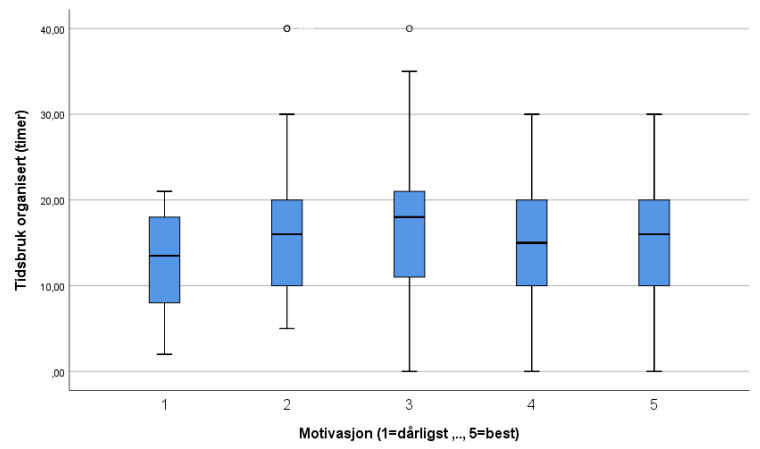

Det teknisk-naturvitenskapelige fakultet

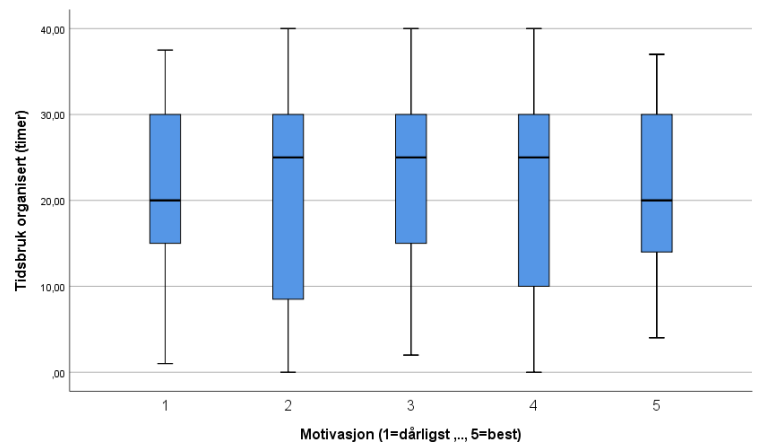

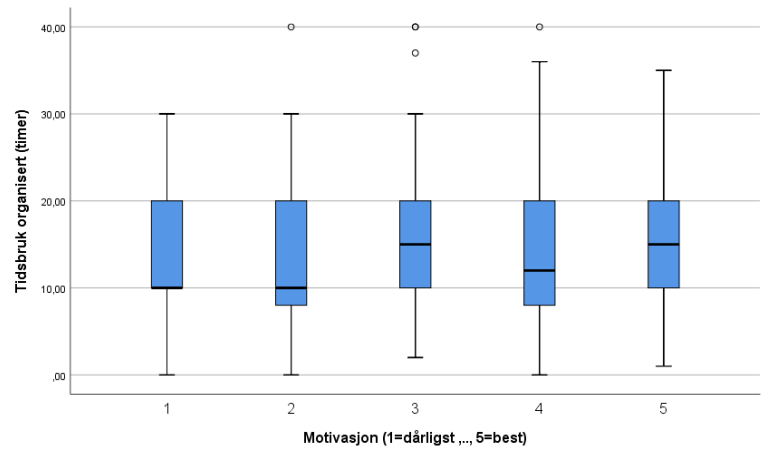

Det samfunnsvitenskapelige fakultet

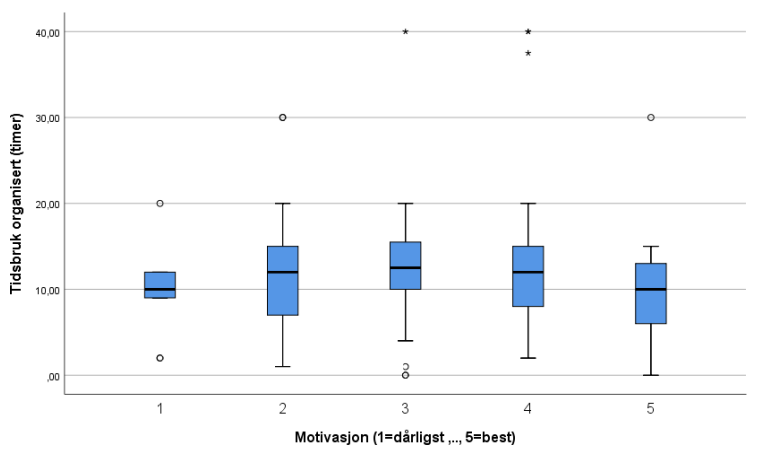

Handelshøgskolen ved UiS

Det helsevitenskapelige fakultet

Fig. 2. Antall timer pr. uke med organiserte loeringsaktiviteter ved hvert av fakultetene ved UiS plottet opp mot studentenes svar på hvorvidt studieprogrammet bidrar til motivasjon for studieinnsats. 


\subsection{Om sammenhengen mellom organiserte læringsaktiviteter og studentenes overordnede tilfredshet med studiet}

For å studere sammenhengen mellom mengden av organiserte læringsaktiviteter og studentenes overordnede tilfredshet med studieprogrammet, så følger vi samme prosedyre som når vi analyserte sammenhengen mellom mengden av organiserte læringsaktiviteter og motivasjon. Vi tar nå utgangspunkt i svar fra studentene på spørsmål om hvor mange timer læringsaktiviteter som er organisert av institusjonen (spørsmål 1) og studentenes tilfredshet med studieprogrammet de går gå (spørsmål 3).

Resultatene er vist i Fig. 3 og Fig. 4. Fra boksplottene så får vi indikasjoner på at det ikke er sammenheng mellom tidsbruken som er organisert av institusjonene og studentenes tilfredshet. Resultatene for hvert av fakultetene samsvarer i stor grad med resultatene for universitetet.

Kruskal-Wallis testen gir en p-verdi $=0.76$ når vi ser på hele UiS samlet, dvs. ingen signifikant sammenheng. Det samme gjelder for de enkelte fakultetene, med p-verdier fra 0.46 til 0.79 .

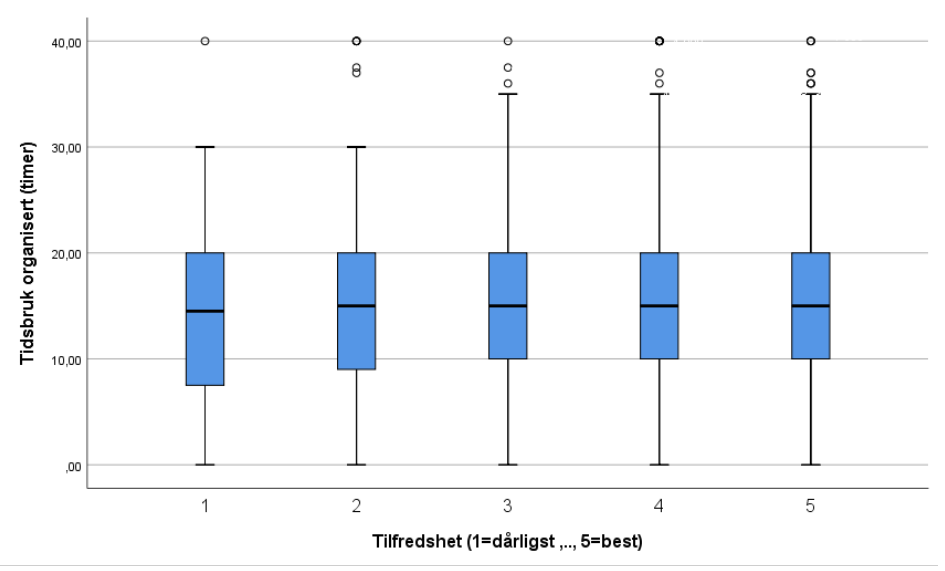

Fig. 3. Antall timer pr. uke med organiserte laeringsaktiviteter ved UiS plottet opp mot studentenes overordnede tilfredshet med studieprogrammet de går på.

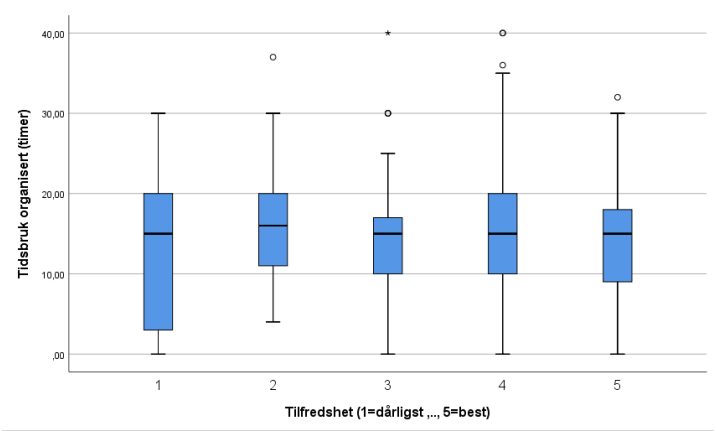

Fakultet for utdanningsvitenskap og humaniora

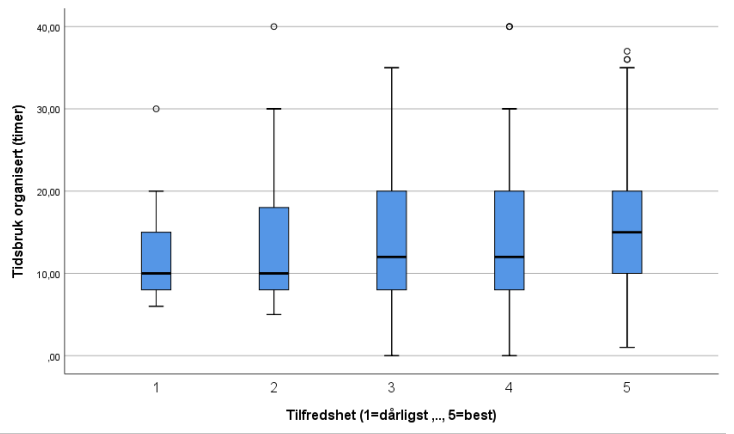

Det samfunnsvitenskapelige fakultet 


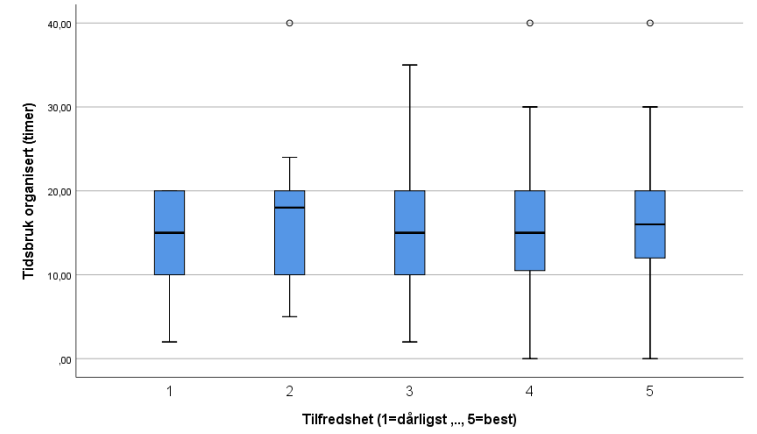

Det teknisk-naturvitenskapelige fakultet

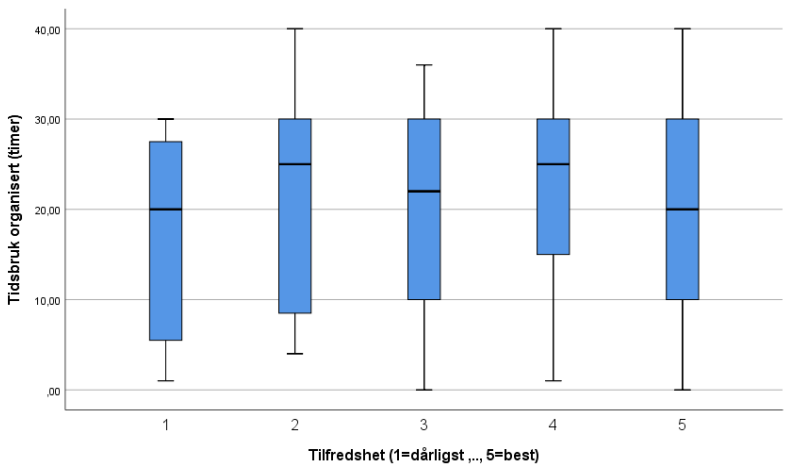

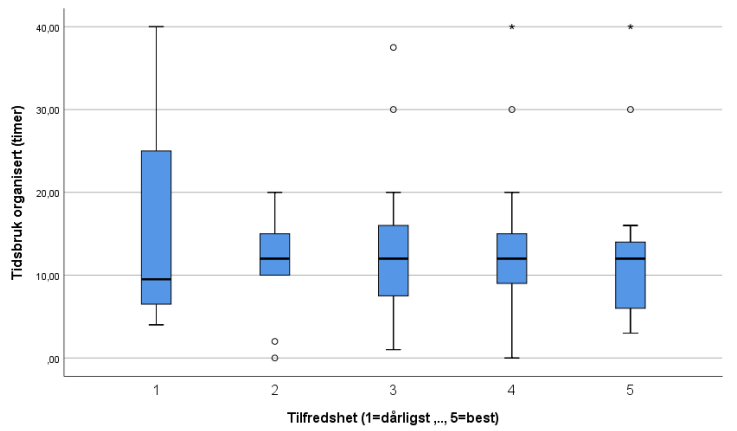

Handelshøgskolen ved UiS

Det helsevitenskapelige fakultet

Fig. 4. Antall timer pr. uke med organiserte loringsaktiviteter ved hvert av fakultetene på UiS plottet opp mot studentenes overordnede tilfredshet med studieprogrammet de går på.

\subsection{Organiserte læringsaktiviteter og dens sammenheng med studentenes egeninnsats}

For å få innsikt i om det er sammenheng mellom mengden organiserte læringsaktiviteter og studentenes egeninnsats så har vi plottet antall timer pr. uke med organiserte læringsaktiviteter opp mot antall timer pr. uke med egeninnsats. Dette er gjort for Universitetet i Stavanger (Figur 5) og for hvert av fakultetene på universitetet (Figur 6). Fra Figur 5 og 6 er det det lite som tilsier at mengden med organiserte læringsaktiviteter organisert av institusjonen påvirker antall timer med egeninnsats i nevneverdig grad. Beregningen viser at korrelasjonen mellom de to størrelsene for Universitetet i Stavanger er så lav som 0.03 ( $\mathrm{p}$-verdi $=0.26)$.

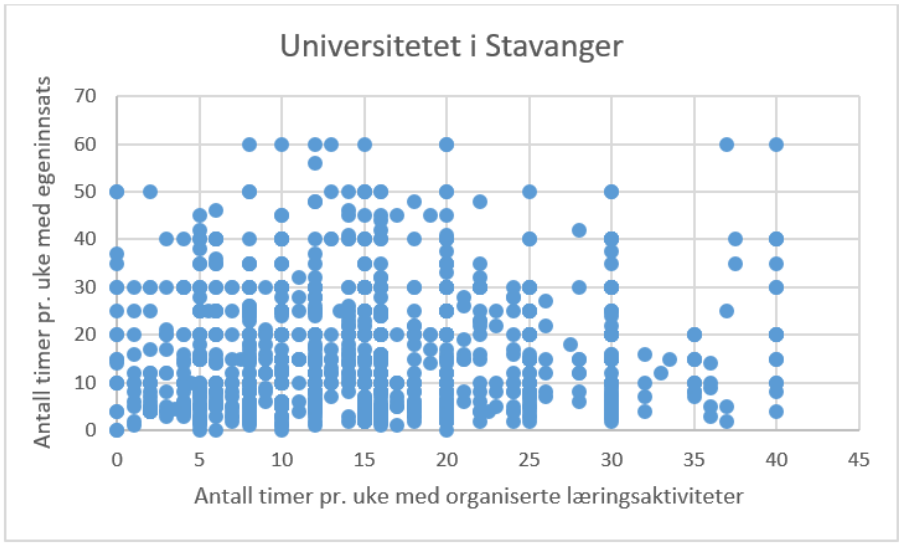


Fig. 5. Antall timer pr. uke med egeninnsats plottet opp mot antall timer pr. uke med organiserte loeringsaktiviteter.
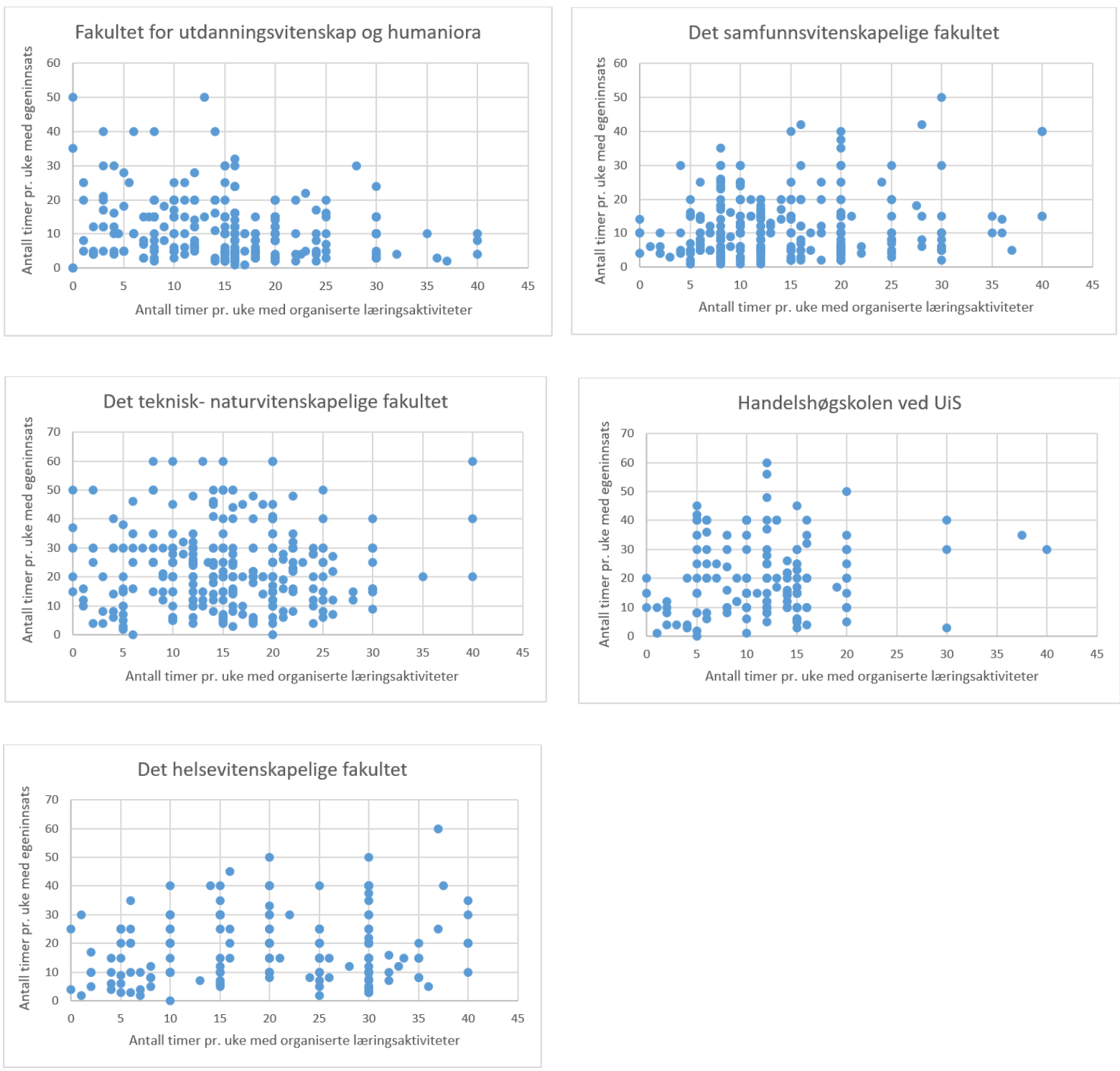

Fig. 6. Antall timer pr. uke med egeninnsats plottet opp mot antall timer pr. uke med organiserte loeringsaktiviteter. Resultatene er presentert på fakultetsnivå.

Korrelasjonen for hvert fakultet over er hhv -0.20 ( $\mathrm{p}$-verdi $=0.002), 0.05$ ( $\mathrm{p}$-verdi $=0.40), 0$ ( $\mathrm{p}$ verdi $=0.96), 0.08$ ( $\mathrm{p}$-verdi $=0.35), 0.10$ ( $\mathrm{p}$-verdi $=0.16)$, dvs. veldig svake/ingen sammenhenger.

\section{DRØFTING}

Basert på analysene presentert i kapittel 4 finner vi ingen signifikante sammenhenger mellom gjennomsnittlig antall timer brukt på organiserte læringsaktiviteter og studentens motivasjon for studieinnsats, egeninnsats eller tilfredshet med studiet. Dette trenger imidlertid ikke å bety at slike sammenhenger ikke finnes, men at sammenhengene kan være mer komplekse enn hva vi klarer å fange opp i denne studien. Det er med dette grunnlag viktig å diskutere didaktiske- og pedagogiske forhold enda tettere på den undervisningen og læringen som foregår. Wiers-Jenssen \& Hovdhaugen (2019), er inne på dette når de viser at det er svak korrelasjon mellom studentenes tidsbruk og nivå forstått som eksamensresultater, og at de heller ikke finner en sterk sammenheng mellom studenttilfredshet og tidsbruk (s. 276). Deres studium peker imidlertid på at studenter som allerede oppgir høy motivasjon bruker mest tid på studiene, og i så måte handler dette også om inntakskvaliteten til studentene, og da 
deres faglige nivå før de kommer til høyere utdanning (Handal, 1990). Vi kommer tilbake til dette, men også det Wiers-Jenssen \& Hovdhaugen (2019) er opptatt av, når de påpeker at universitetslærere sine forventninger til studentene har en positiv effekt på deres studieinnsats. Det handler om hvordan uttrykke faglige forventninger og synliggjøre hvordan studentene skal lære det de skal lære til et mangfold av studenter (Meld. St. 16, 2016-2017, s. 23, s. 31, s. 41). Studentvariasjonen er stor i dagens høyere utdanning, og universitetslærere må diskutere didaktisk og pedagogisk hvordan de kan sikre best mulig læringsutbytte for hver enkelt student.

\section{Kvaliteter ved de organiserte loeringsaktivitetene}

Det å lete etter kvaliteter ved et studietilbud, vil innebære å måtte se etter kjennetegn ved læringsaktivitetene som studentene vurderer som attraktive og gode. Men det vil også handle om en erfaring og vurdering av at det å delta på læringsaktivitetene er tett koblet til et læringsutbytte som for studentene er klart uttrykk og oppleves som relevant. Kvernbekk beskriver dette som utdanningens indre og ytre relevans (Kvernbekk, 2012). Den indre relevansen handler om at studentene oppfatter at studiet er knyttet tett til eksisterende forskning og til et etablert vitenskapsområde, og at læringsaktiviteten er tett koblet til læringsutbyttebeskrivelser. Men det handler også om at studentene ser en ytre relevans med det de gjør, og da at de organiserte læringsaktivitetene oppfattes som hensiktsmessige i forhold til et fremtidig yrke. At studentene oppfatter indre og ytre relevans kan føre til at studentene motiveres, at de bruker mer tid på studiet (egeninnsats), og at de er generelt mer fornøyde med studiet. En tidligere studie fra Universitetet i Stavanger (Abrahamsen et. al., 2020) bekrefter at det er en positiv sammenheng mellom studentenes motivasjon og studentaktiv undervisning, og mellom studentenes motivasjon og de faglig ansattes evne til å gi konstruktive tilbakemeldinger. Når det gjelder grad av studentaktiv undervisning og dens innvirkning på studentenes motivasjon, så vil variasjon av læringsaktiviteter, slik som Jakobsen \& Waldenstrøm (2017) og Hyun, Ediger \& Lee (2017) viser i sine empiriske studier også være viktig. Men det er ikke variasjon for variasjonens skyld som er poenget, men å lære på flere ulike måter for å nå komplekse kunnskaps-, ferdighets- og kompetansemål. Studentene må få øve seg og arbeide på mange måter for å utvikle mange kompetanser som trengs både for å være en ekspert $\mathrm{i}$ et fagområde, men også for å kunne være en kompetent arbeidstaker i dagens komplekse arbeidsliv. Det at studentenes arbeidsmåter er varierte, og på samme tid synliggjort for dem som koblet til både indre og ytre relevans ved et vitenskaps- og profesjonsområde, vil kunne stimulere til økt arbeidsinnsats og motivasjon.

Kvaliteter ved selve samhandlingen mellom studenter og de faglige ansatte, som for eksempel at studentene støttes og utfordres gjennom konstruktive tilbakemeldinger, synes også å bidra til økt studieinnsats og motiverte studenter. Schneider \& Preckel (2017) peker for eksempel på at studenters læring og tilfredshet handler om å bli sett både personlig og faglig. Det å styrke frekvensen og kvaliteten på formative vurderinger knyttet til studentenes arbeid underveis, vil innebærer «å se dem» hyppigere som enkeltstudenter gjennom innleveringer og tilbakmeldingssløyfer av hvor de står faglig sett i forhold til de læringsutbytteformuleringer gitt. Dette vil på samme tid som å lede deres læring tett og individuelt, kunne gi muligheten til å anerkjenne deres innsats så langt og motivere for ytterliggere innsats.

Som også NIFU rapporten 'Quality in Norwegian Higher Education - A review on aspects affecting student learning' (Damsa et. al., 2015) er inne på, så vil vi argumentere for at det er et pedagogisk og didaktisk anliggende at studentene selv ser relevansen av sin utdanning og opplever anerkjennelse og det å bli sett. Vi oppfatter at dette er kvaliteter ved læringsaktivitetene som vil kunne motivere dem for $ø \mathrm{kt}$ grad av deltakelse og studenttilfredshet. Vi mener derfor at det er viktig for studentene at universitetslærere er transparente og eksplisitte på de didaktiske sammenhenger som gjelder i et emne, forstått som det artikuleres hvordan didaktiske kategorier som læringsmål, arbeidsmåter, faginnhold og vurdering henger sammen (Bjørndal og Lieberg, 1978). Som Dale (1989) påpeker, så må studentene få en tydelig forklaring på hva de skal lære, hvordan de skal lære det de skal lære, og hvorfor de skal lære det de skal lære. Disse tre såkalte didaktiske spørsmålene, må svares ut ikke bare i en planleggingsfase av universitetslærer selv, men kommuniseres til studentene underveis i læringsprosessen. Universitetslærere må meta-kommunisere hvordan et fagemnet didaktisk henger sammen underveis i læringsforløpet slik at det blir tydelig for studentene hva de er involvert og hvor de til enhver tid er i forhold til de faglige mål som er satt (Bateson, 1972; Husebø, 2012). 
Insentiver og utenforliggende årsaker for grad av deltakelse og motivasjon i laeringsaktiviteter

Den kvantitative analysen tilsier videre at det ikke trenger å være slik at det å tilrettelegge for mange læringsaktiviteter bidrar til høy studentmotivasjon og -tilfredshet. Det kan også være andre forhold eller insentiver som utfordrer denne deltagelsen, som gjør at studentene i mindre grad finner muligheter for å delta på mange læringsaktiviteter. Slike forhold kan være at de er i en jobbsituasjon som gjør det vanskelig å delta, eller at studentene i studiet har tilgang til digitale læringstilbud som gir tilsynelatende samme utbytte, f.eks. i forhold til eksamensresultat.

Videre, hvis det digitale tilbudet (video-forelesninger, e-læringsoppgaver, osv.) anses å være tilsvarende det de ellers har opplevd på campus, så vil det være færre studenter som møter opp på fysisk undervisning. Et digitalt undervisningstilbud vil uten at det foretas en transformativ omlegging fra en tradisjonell analog forelesningssituasjon til en mer aktivitetsdrevet undervisning (Puentedura, 2014), føre til at studenter i mindre grad deltar aktivt i undervisningen eller trenger å følge samme tempo eller plan. For noen studenter vil dette tilsynelatende være hensiktsmessig og ønskelig, og de vil i så måte kunne score høyt som motiverte og fornøyde med studiet i Studiebarometeret. Av samme grunn vil de imidlertid kunne score lavt på deltagelse på organiserte læringsaktiviteter, og i et didaktisk- og pedagogisk perspektiv mest sannsynlig også lære mindre. Studenter som prioriterer video-forelesninger og digital tilstedeværelse, fremfor oppmøte på campus og en bredere undervisningsaktivitet, vil kunne stå $\mathrm{i}$ fare for å miste muligheter til interaksjon med universitetslærere og medstudenter som er avgjørende for å lære seg det brede og komplekse spekteret av kunnskaper, ferdigheter og generell kompetanse som ligger til et universitets- og høgskolestudium. Samhandling og dialog i klasserommet fører til tolkninger av det som foregår som både innebærer at undervisningsmåter justeres og tilrettelegges for studentenes læring, men også at studentene selv justerer sin måte å være lærende på gjennom sine møter med medstudenter og lærere (Ramirez 2020). Vår evne til å lære av hverandre og lære til hverandre krever stor grad av relasjonell samhandling (Wadel, 2005), en samhandling som er mer forpliktende og engasjerende når den foregår ansikt til ansikt og som fysisk tilstedeværelse.

Et annet aspekt er at det å tilby en stor mengde med organiserte læringsaktiviteter kan bidra til lavere kvalitet på disse, og at det går ut over andre aktiviteter som skulle vært vektlagt mer. Universitetslærer har en viss tilmålt tid til planlegging, gjennomføring og vurdering av den undervisningsaktivitet som skal gjennomføres, og da bør det gjøres prioriteringer av både mengde og hvordan læringen skal organiseres ut fra det som skal læres. Tidspresset som mange universitetslærere opplever kan ha flere årsaker, som også vises til i NOKUT-rapporten «Tidspress i undervisning og veiledning i høyere utdanning - En utfordring for kvaliteten i utdanningen?» (Amundsen og Øygarden 2019). I rapporten uttrykkes en bekymring for hvordan tidspresset kan påvirke utdanningskvaliteten. Vi vil med andre ord kunne få et positivt bidrag med mer organiserte læringsaktiviteter (i seg selv), men at den høye graden av organiserte læringsaktiviteter vil kunne gi et negativt utslag på kvalitet totalt sett.

\section{Studentenes faglige nivå og sosiale forhold}

Studentene har naturlig nok ulike forutsetninger og forventninger til studiene. Det er rimelig å anta at studenter som er motiverte, faglig ressurssterke og som ønsker en god karakter uansett legger ned en stor mengde egeninnsats, men at de vil gjøre dette nokså uavhengig av mengden organiserte læringsaktiviteter. Samtidig er det rimelig å anta at andre studenter bruker lenger tid for læring ved at fagstoff anses for å være mer krevende og/eller mindre interessant. Av den grunn vil ikke egeninnsatsen være veldig forskjellig mellom studenter med hel ulikt utgangspunkt.

Det faglige nivået til studentene har betydning for hvordan de tilnærmer seg faglig innhold og den læringsaktiviteten som pågår. Noen studenter vil som gruppering ha generelt større behov for oppfølginger og tilbakemeldinger, og vil trolig søke og ha behov for mer deltagelse i organiserte læringsaktiviteter. Hvorvidt de er fornøyde eller ikke, handler ikke bare om hvorvidt aktivitetene bidrar til læring, men også hvorvidt studiet møter deres forventninger. Studenter som legger ned mye tid og arbeid og samtidig føler at de ikke oppnår forventet læringsutbytte gjennom graderte karakterer, vil ha grunn til å vise mindre motivasjon. Kantardjiev (2019) påpeker at det er viktig for motivasjonen at studentene føler mestring og at de oppfordres til å tenke kompetansebygging fremfor fokus på 
prestasjoner og karakterer. Motivasjon bidrar til at studentene har høyere utholdenhet og klarer å verdsette læringsaktivitetene som «ikke er direkte motiverende i seg selv» (Kantardjiev, 2019).

Angående deltagelse, så vil flere studenter ha en høy grad av deltagelse på organiserte læringsaktiviteter på grunn av karakteristikker ved disse, ved at de er obligatoriske eller nødvendige for å gjennomføre studiet. Det kan være laboratorieøvinger, eller andre typer veiledet aktivitet, hvor studentene forventes å delta og hvor det ikke foreligger et godt digitalt alternativ. For studenter som ønsker primært digital undervisning, så kan denne type læringsaktiviteter oppleves mindre motiverende ved at det påvirker deres autonomi ved krav til oppmøte, og nødvendigvis bidrar til at man har mindre tid til egeninnsats på egne vilkår.

Samtidig danner studentene gjerne grupperinger som har et noenlunde felles syn på hvordan læring og gode eksamensresultater best oppnås. Det sosiale aspektet har ikke nødvendigvis så mye påvirkning på selve læringen, med mindre det aktiviserer studentene. De sosiale arenaene er klart viktige for å få tilbakemeldinger og diskusjoner mellom studenter. For enkelte studenter vil det sosiale fellesskapet virke som en drivkraft. Men det kan også virke motsatt, ved at det er enkeltstudenter som utfordrer den sosiale interaksjonen underveis. Slike forhold kan således være viktig for studentenes motivasjon og for om studentene er fornøyde med de organiserte læringsaktivitetene.

\section{Gyldighet for analysen}

Analysen bygger på et omfattende datagrunnlag, hvor over 1700 studenter har gitt sine tilbakemeldinger, eksklusive de 22 som ble fjernet i hver av analysene grunnet urimelige verdier. Som tidligere nevnt, så anses dette for å være et utvalg som gir et godt bilde av hele studentmassen ved UiS. Svarprosenten for UiS-dataene var 11 prosentpoeng høyere enn tilfellet var for det nasjonale utvalget, hvor svarprosenten var på 48\% (NOKUT, 2019). Med unntak av Fakultet for utøvende kunstfag og av for Etter- og videreutdanningen ved UiS, så bør det være tilstrekkelig datagrunnlag til å trekke slutninger angående sammenhengene vi har studert.

Det kan stilles spørsmål ved om de dataene som er fjernet, er urimelige, som vurdert $\mathrm{i}$ analysen. Her mener vi at det ikke tilrettelegges for organiserte aktiviteter utover 40 timer per uke, og at de som har registrert flere enten har registrert feil eller at de deltar på flere emner enn det studieprogrammet tilsier. Hvis tilfellet er at de deltar på flere studier, eller tar studier over kortere tid, og slike varianter, så anser vi det uansett som urimelig å se disse registreringene som representative. Videre så utgjør de 22 så liten del av det totale tallmaterialet at det ikke endrer noen konklusjoner om de ekskluderes.

For registreringene av egeninnsats høyere enn 60 timer per uke, så er dette naturligvis mulig. Men det er mer trolig at disse tallene da uttrykker en sum av egeninnsats og organiserte læringsaktiviteter. Det kan skyldes at studentene har misforstått hva som ligger i «egeninnsats» og har rapportert all sin studietid under denne kategorien. Det kan også tenkes at enkelte studenter velger bort og organiserte aktiviteter og bruker mer tid som følge av dette. Slik sett kan det faktisk være enkeltstudenter som bruker 60+ timer. Men ettersom vi oppfatter en betydelig usikkerhet i disse tallene, har vi valgt å fjerne disse. Siden disse registreringene er så få gir det å utelate disse kun helt marginale utslag på analysen og sammenhengene vurdert.

Det kan også stilles spørsmål generelt om studentene faktisk har svart på spørsmålene som tiltenkt, som også er diskutert for den nasjonale undersøkelsen (NOKUT, 2019). Nivå på studentenes motivasjon, egeninnsats og fornøydhet er ikke nødvendigvis faktisk det som studentene selv rapporterer. Det samme gjelder for antall timer brukt (egeninnsats og deltagelse på organiserte læringsaktiviteter), som har en viss grad av usikkerhet bl.a. relatert til om studentene oppfatter spørsmålene korrekt. Til slutt er det også en faktor at selv om vi har en høy svarprosent så kan det likevel være noe skjevhet i hva de som har valgt å svare på undersøkelsen rapporterer i forhold til hva dataene for de øvrige studentene ville vært.

\section{KONKLUSJON}

Analysene av data fra Studiebarometeret tyder på at mengden av organiserte læringsaktiviteter ikke som enkeltstående faktor påvirker studentenes motivasjon. Det samme gjelder for studentenes overordnede tilfredshet med studieprogrammet de går på, hvor vi heller ikke finner noen signifikant sammenheng. 
Dataene viser også at mengden med egeninnsats i stor grad er upåvirket av mengden av læringsaktiviteter som organiseres av institusjonene.

Analysene er basert på totalt 1710 tilbakemeldinger fra studenter ved UiS fra undersøkelsen gjennomført i 2018. Hele 59\% av studentene svarte på undersøkelsen, som gir et omfattende datagrunnlag og som igjen bør gi et representativt bilde av situasjonen ved denne utdanningsinstitusjonen. Selv om det er trolig at resultatene vil være representative på et nasjonalt nivå, så vil vi være forsiktige med å trekke noen slike konklusjoner.

For videre studier, kunne det være interessant å undersøke nærmere ulike andre årsaksforhold og sammenhenger som vi har drøftet her i denne artikkelen, om de spiller inn og gjør at vi ikke finner signifikante kvantitative sammenhenger i forhold til mengden læringsaktiviteter og studentenes motivasjon og tilfredshet. Basert på funnene knyttet til det forskningsspørsmålet vi stilte for denne artikkelen, er det lite som tilsier at det å øke organiserte læringsaktiviteter alene har en ensidig positiv effekt på studentenes egeninnsats, motivasjon og tilfredshet. Allikevel har vårt forsøk på å svare på spørsmålet ført oss inn i diskusjoner og refleksjoner om det er typer læringsaktiviteter som kan ha spesielt god effekt på studentenes motivasjon og læring. Da tenker vi på læringsaktiviteter hvor studentene aktiviseres i konstruktive tilbakemeldingssløyfer knyttet til deres faglige arbeid underveis i studiet. Større mengder av gjensidig samhandling mellom studenter og faglærer som baserer seg på innleverte studentarbeider og faglige formative tilbakemeldinger på disse, vil kunne føre til større grad av involvering av studentene i akademias egne fagfelleorienterte læringsprosesser, og bidra positivt for deres læring. Om denne type didaktiske og pedagogiske grep vil føre til økt grad av uttrykt motivasjon og tilfredshet i studiebarometersammenheng, er imidlertid ikke godt å si med grunnlag i studien gjort her, men samtidig innbyr våre funn og diskusjoner til å gi retning til enda mer kritisk og vitenskapelig forskning på utdanningsområdet.

\section{REFERANSER}

Abrahamsen, E.B., Selvik, J.T., Moen, V. \& Kvaløy, J.T. (2020). Om sammenhengen mellom motivasjon, studentaktiv undervisning og konstruktive tilbakemeldinger. En studie fra universitetet i Stavanger. Akseptert for publisering i Tidsskrift for høgskole- og universitetspedagogikk. https://doi.org/10.18261/issn.18938981-2020-04-03.

Amundsen, G.Y. \& Øygarden, K.F. (2019). Tidspress i undervisning og veiledning av studenter i høyere utdanning: En utfordring for kvaliteten i utdanningen? NOKUT rapport 17-2019. https://www.nokut.no/globalassets/nokut/rapporter/ua/2019/amundsen_oygarden_tidspress-i-undervisningog-veiledning-i-hoyere-utdanning_17-2019.pdf

Bakken, P., Pedersen, L., Wiggen, K. \& Øygarden, K. (2019). Studiebarometeret 2018: Hovedtendenser (NOKUT Rapport 1-2019). Hentet fra https://www. nokut. no/globalassets/studiebarometeret/2019/studiebarometeret-2018_hovedtendenser_1-2019. pdf.

Bateson, G. (1972). Steps to an Ecology of Mind, Chicago, Illinois: University of Chicago Press.

Bjørndal, B. \& Lieberg, S. (1978). Nye veier i didaktikken. Oslo: Aschehoug.

Dale, E. L. (1989). Pedagogisk profesjonalitet: om pedagogikkens identitet og anvendelse. Oslo: Gyldendal.

Damşa, C., de Lange, T., Elken, M., Esterhazy, R., Fossland, T., Frølich, N., ... Nordkvelle, Y. T. (2015). Quality in Norwegian Higher Education: A review of research on aspects affecting student learning.

Damşa, C. \& de Lange, T. (2019). Student-centred learning environments in higher education. Uniped, 42(01), 9 26. https://doi.org/10.18261/issn.1893-8981-2019-01-02.

Freeman, S., Eddy, S. L., McDonough, M., Smith, M. K., Okoroafor, N., Jordt, H. \& Wenderoth, M. P. (2014). Active learning increases student performance in science, engineering, and mathematics. Proceedings of the National Academy of Sciences, 111(23), 8410-8415. https://doi.org/10.1073/pnas.1319030111.

Handal, G. (1990) Studiekvalitet - Innstilling fra Studiekvalitetsutvalget avgitt til Utdannings- og forskningsdepartementetet. https://www.nb.no/nbsok/nb/84c5d84cefd1c378aa5652a4af32cb11?lang=n $\# 0$

Husebø, D. (2012). Bridging theory and practice in Norwegian teacher education, Educational action research, Taylor and Francis, Vol.20, Nr. 3, p. 455-471. https://doi.org/10.1080/09650792.2012.697665.

Hyun, J., Ediger, R. \& Lee, D. (2017). Students' Satisfaction on Their Learning Process in Active Learning and Traditional Classrooms. International Journal of Teaching and Learning in Higher Education, 29(1), 108-118. 
Jakobsen, A. N. \& Waldenstrøm, L. (2017). Fra lærerstyrt undervisning til varierte læringsformer,1(1), 319-327. https://doi.org/10.5324/njsteme.v1i1.2330.

Kantardjiev, K.O. (2019). Studentaktiv læring og diversitet - hva fungerer og hvorfor? NOKUT rapport 11-2019. https://www.nokut.no/globalassets/nokut/rapporter/ua/2019/kantardjiev_studentaktiv-laring-ogdiversitet_11-2019.pdf

Kvernbekk, T. (2012). Kriterier i forskning: Hva er de, hvor kommer de fra, og hvordan skal vi legitimere dem? i (red.) T. Løkensgaard-Hoel, B. Hanssen og D. Husebø. Utdanningskvalitet og undervisningskvalitet under press? - Spenninger $i$ høgere utdanning. Trondheim: Tapir akademiske forlag, s. 47 - 76

Meld. St. 16 (2016-2017). Kultur for kvalitet i høyere utdanning. Oslo: Kunnskapsdepartementet.

Nokut. (2019). Studiebarometeret 2018: Hovedtendenser. Studiebarometeret: Rapport 1-2019.

Nerland, M. (2019). Kvalitetsarbeid i studieprogrammene: fagene som kontekst for studentaktivisering og kunnskapsintegrasjon. Uniped, 42(01), 111-117. https://doi.org/10.18261/issn.1893-8981-2019-01-09.

Newbold P, Carlson W, Thorne B. 2019. Statistics for Business and Economics, $9^{\text {th }}$ Edition. Pearson.

Otnes, B., Thorsen, L. R., \& Vaage, O. F. (2011). Levekår blant studenter 2010. SSB Rapporter, (36) Oslo.

Puentedura, R. R. (2014). SAMR and TPCK: A Hands-On Approach to Classroom Practice. www.hippasus.com/rrpweblog/archives/2014/12/11/SAMRandTPCKk_HandsOnApporachClassroomPr actice. $p d f$.

Ramirez, C. (2020). Å lære studentene kritisk refleksivitet gjennom lærerens pedagogiske sensitivitet $\mathrm{i}$ undervisningen. Vol. 5 No. 1 (2020): Læring om læring, 5(1); https://www.ntnu.no/ojs/index.php/lol/article/view/3820.

Schneider, M. \& Preckel, F. (2017). Variables associated with achievement in higher education: A systematic review of meta-analyses. Psychological bulletin, 143(6), 565. http://doi.org/10.1037/bul0000098.

Wadel, C. (2005). Samhandling og relasjoner. Flekkefjord: Seek A/S

Wiers-Jenssen, J., Stensaker, B., \& Grøgaard, J. B. (2002). Student Satisfaction: Towards an empirical deconstruction of the concept. Quality in Higher Education, 8(2), 183-195.

https://doi.org/10.1080/1353832022000004377.

Wiers-Jenssen, Jannecke (2014). Studentenes vurderinger av utdanning og lærested. I N. Frølich, E. Hovdhaugen \& L. I. Terum (red.), Kvalitet, kapasitet og relevans. Utviklingstrekk $i$ norsk høyere utdanning. Oslo: Cappelen Damm Akademisk.

Wiers-Jenssen, J. \& Hovdhaugen, E. (2019). Studieinnsats på lavere grad-hva kan Studiebarometeret fortelle oss? Uniped, 42(03), 274-289. https://doi.org/10.18261/issn.1893-8981-2019-03-04. 